Max-Planck-Institut für demografische Forschung

Max Planck Institute for Demographic Research

Doberaner Strasse 114 - D-18057 Rostock · GERMANY

Tel +49 (0) 3812081 - 0; Fax +49 (0) 3812081 - 202;

http://www.demogr.mpg.de

MPIDR WORKING PAPER WP 2001-028

SEPTEMBER 2001

Children's experience of family

disruption and family formation: evidence from 16 FFS countries

Gunnar Andersson (andersson@ demogr.mpg.de)

This working paper has been approved for release by: Jan M. Hoem (hoem@ demogr.mpg.de) Head of the Laboratory of Contemporary European Fertility and Family Dynamics.

C) Copyright is held by the authors.

Working papers of the Max Planck Institute for Demographic Research receive only limited review. Views or opinions expressed in working papers are attributable to the authors and do not necessarily reflect those of the Institute. 


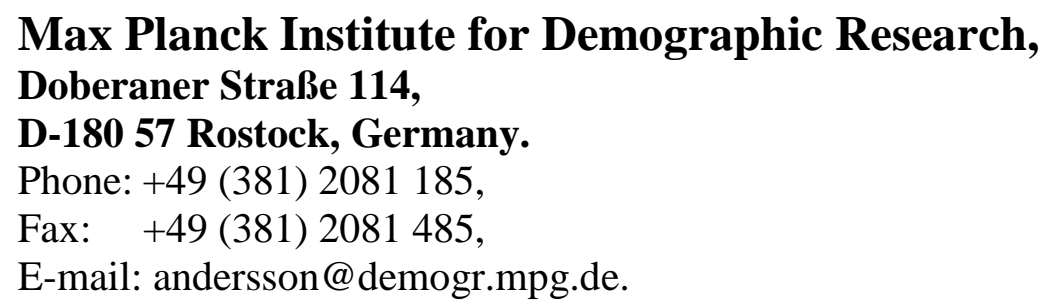

GA, 3 August 2001

\title{
Children's experience of family disruption and family formation: evidence from 16 FFS countries
}

\author{
by Gunnar Andersson
}

\begin{abstract}
In this paper, we present a number of descriptive measures on children's experiences of family disruption and family formation. We use data from the Fertility and Family Surveys of 15 European countries and corresponding data from the USA in order to find out what kind of family circumstances children are born into and which experiences they subsequently have of various family-transformation events of their mothers. Our presentation reveals some similarities but also striking differences in the family-demographic experience of children in different countries. USA stands out as one extreme case with its very high fraction of children born to a lone mother, with a higher probability for children to experience a union disruption of their parents than anywhere else, and with many children having the experience of living in a stepfamily. Italy stands out at the other end of the scale. Practically all children are here born to a married mother and very few of them experience a dissolution of their parents' union before they turn 15 .
\end{abstract}

Paper presented for the XXIVth IUSSP General Population Conference in Salvador, Brazil, 18-24 August 2001. 


\section{Introduction}

The last three decades have witnessed an upsurge in research on various aspects of the family dynamics of people in developed countries. An increased attention to changes in patterns of family formation and family dissolution and to consequences of such changes follows the observed increase in the variation of how people tend to organize their family lives. Attention has, for example, been given to the fact that people in many European countries today often live together in unions without being married (Murphy, 2000; Prinz, 1995; Toulemon, 1997). Consequently, the marital status of people is far from sufficient if one wants to get an accurate picture of their family status (Bumpass and Raley, 1995). We still need more and better descriptions of the present state of family-demographic affairs in contemporary European countries. It is indeed important to first know exactly how the situation looks like before one tries to explain it, and it is particularly important to get a better picture of various differences and similarities in demographic behavior between the different countries in Europe. In some cases, the perception of a very volatile situation in the domains of family demography might turn out to be a bit exaggerated. The situation is not always as dynamic as one might think it is when one reads research materials stemming from, for example, the US.

There are not that many large-scale cross-country comparisons available in this field of research but Kiernan (1999a,b, 2000) provides such comparisons when she focuses on the status of unions in Western Europe and the context of childbearing there. Klijzing and Macura (1997) provide another example of an overview of the family context for childbearing in Europe. Heuveline and Timberlake (2000) present an encouraging cross-country comparison of the state of family demography when they examine the experiences of different living arrangements and family types of children in a wide range of European countries. The previous lack of studies that describe the family demographic situation from the point of view of children is otherwise to regret since the attention from researchers on processes like divorce often is motivated by the concern for children involved. When studying the family dynamics from children's perspective, it is of course particularly important to be able to get a picture of their parents' actual living arrangements rather than just that of their marital status (Bumpass and Raley, 1995; Bumpass and Hsien-Hen, 2000). 
In our study, we present a number of descriptive measures on children's experiences of various family-demographic events. Our study is a cross-country comparison and, like the comparative studies we referred to above, it is based on data derived from the first round of European Fertility and Family Surveys (FFS). We use data as reported by children's mothers from 16 countries - from countries in Western and Eastern Europe and from the USA - in order to estimate to what extent children experience events like a union disruption of their parents or a union formation of their lone mother. We present separate calculations for children born to a lone mother, children born to a cohabiting mother, and children born in marriage so that we can depict the different family-transformation events that can occur in each type of family. For children who experience a union disruption of their parents, we examine to what extent they experience the formation of a new union of their mother. In our comparison, we present results for different ages of children so that we can follow a typical child from its birth to the $15^{\text {th }}$ birthday.

\section{Data and methods}

Our presentation is based on a number of tabulations by Andersson and Philipov (2001a,b). They have estimated a relatively large number of life tables over children's various experiences of different family-transformation events between ages 0 and 15, in addition to other sets of life tables that describe the experiences of adult men and women of various family-formation and family-dissolution events of interest. Their system of description of demographic behavior is presented in more detail in Andersson and Philipov (2001a) while Andersson and Philipov (2001b) provides the full database of tabulations. The tabulations are based on raw data gathered at the Fertility and Family Surveys that were conducted in a large number of European countries in 1989-1997. The US National Survey of Family Growth from 1995 gives comparable data for the USA so that patterns in Europe can be compared to those that prevail on the other side of the Atlantic. For each country, we present the cumulative percent of children who have ever experienced a certain family-demographic event at selected ages so that we can use it in a broad cross-country comparison. Our life-table estimates are based on the children's mothers' reports of various union-formation and union-dissolution events. We do not use the information reported by fathers since 
large segments of children's lives are missing in their reports. In most cases, children live with their mother if they don't live with both parents, so mother's reports give a better coverage of the actual living arrangements of their children. Our life tables are based on the idea of a synthetic cohort. They are calculated from reported events of a specific kind and exposures to that event during a period of six years immediately before each survey date so that they describe the pattern of family-demographic affairs during that calendar period. We also present a few summary measures of children's family experiences, such as the fractions of time that are spent in different family types during childhood, again calculated from information relating to the sixyear period we cover. We have calculated life tables for the following countries ${ }^{1}$ : Sweden, Norway, Finland, France, USA, Austria, Germany, Flanders ${ }^{2}$, Italy, Spain, Czech Republic, Hungary, Slovenia, Latvia, Lithuania, and Poland. East and West Germany are treated separately. For East Germany, we use the six-year period immediately before the political turnaround in November 1989 as our study period, which thus refers to the former GDR. Before calculating the various life-table measures that we present here, we had to perform a considerable amount of data cleaning. The raw data for Austria and Germany, just to mention one example, contained a large number of observations with missing dates of union formation and union dissolution of respondents so we had to exclude them from our calculations. Table 1 contains the total number of female respondents, mothers, and children of these respondents that, for each country, remain in our data set after our cleaning procedures. In our calculations, we have subsequently used the parts of the data that refer to our synthetic cohorts of interest. We have applied weights in our calculations of life-table estimates for France and the US since the sampling procedures in these countries were performed in a way that were dependent on the outcomes we want to study. For further details concerning our data and our system of life-table descriptions, see Andersson and Philipov (2001a,b).

\footnotetext{
${ }^{1}$ The FFS data from Netherlands and Estonia have not been made available to us. Data from Bulgaria and Portugal do not contain union histories of respondents and cannot be used for calculations like ours. We have not (yet) made calculations for Switzerland and overseas New Zealand and Canada. We hope to be able to apply our system of description to survey data from Great Britain in the near future.

${ }^{2}$ The Belgian FFS only covers the Flemish-speaking parts of the country.
} 


\section{Results}

We begin with a presentation of the distribution of births over different types of families in the various countries under investigation. We then proceed with a description of the various family-transformation events that children born in different types of families experience from their birth to the month they turn 15 .

\section{3a. Distribution of births}

Table 2 contains the relative distribution of births during our period(s) of interest that were reported as occurring while the mothers were not living in a union, and while they were living with a partner in a consensual union, or in a marriage, respectively. We note that two countries stick out with an exceptionally high fraction of births to lone mothers: USA with 17 percent of reported births and the former GDR with a figure of 18 percent. As we will see in our next table, substantial fractions of such children in the GDR soon found themselves living together with their mother and a partner of hers. We have no information on whether this partner normally was their father but other information tells us that most births to lone mothers in the GDR occurred to women living in so called living-apart-together relationships. These were typically mothers who had not yet managed to find the proper housing for themselves and their partner (Alt, 2001, p. 89; see also Dennis, 1999, for a discussion of the phenomena of lone motherhood in East Germany). Relatively high fractions of births to lone mothers, around 10 percent of newborn children, are otherwise reported also for France, Austria, Latvia, and Poland. In the rest of Europe, such events are fairly uncommon. For a few Catholic countries in Western/Southern Europe, notably Italy, Spain, and the Flemish parts of Belgium, we find that no more than 1-2 percent of reported births occur to lone mothers.

If we also have a look on the marital status of the parents of newborn children, we find that children typically are born in matrimony. This is particularly the case in a number of Catholic countries in Southern and Eastern Europe. During our study period, it is actually only in Sweden where it is very common that childbearing occurs to unmarried parents, living in a consensual union. Around half of all children were here born out of wedlock. For Norway, France, and Austria, we find moderately high 
fractions of births, around 20 percent, occurring to cohabiting but not married mothers.

\section{3b. Children's experiences of family formation}

In Table 3, we describe what happens to children born to lone mothers in the various countries in that we report the fractions of such children who are estimated to live with their mother and a partner of hers, being unmarried or not, at the exact ages 1, 3, and 9 years. Evidently, the majority of children born to a lone mother end up living in a two-parent family at some point in time. In some countries, this process occurs very fast. For Italy and Spain, we find that half of the very few children who are born to a lone mother live in a two-parent family already one year after the birth date, indicating that union formation just took place immediately after the child was born (and most probably involved the father of the child). For these countries, we are unable to report any further figures above that age of the child, since the number of observations then are so few that they do not allow for any reliable estimation. A particularly fast process of family formation of lone mothers is also found in the GDR and Slovenia. The prevalence of childbearing to lone women is here higher so we get enough observations to follow their children up to higher ages and discover that as much as 85-87 percent of them have had the experience of living in a two-parent family when they turn nine.

\section{3c. Children's experiences of family dissolution}

Table 4 tells us what happen with the children who are born in a union, which in every country is the dominating group of children, when it comes to their experience of any union disruption of their parents. The percent of such children who have ever experienced a family dissolution is reported at ages 1, 3, 9, and 15 years. Two countries show up as having particularly high levels of disruptions of child families: USA and Latvia. USA has higher fractions of children with an experience of family dissolution than any other country; 40 percent of children born in a union there have had such an experience when they turn 15 . Sweden and the two parts of Germany also 
have relatively high levels of child-family dissolution; around 30 percent of corresponding children there have such an experience before they turn 15. At the other extreme, we find Italy. Only seven percent of children born in a union will there experience a family dissolution during childhood. Such an event is also fairly uncommon for corresponding children in Spain, Slovenia, and Poland, where the comparable figures all stands at 10 percent. Elsewhere in Europe, it is common to find a national figure of around 20 percent. A separate calculation of mean ages of the children that experience a family dissolution of their original parents (not shown here) reveals that such an event typically occurs at an age of 6-8 years, no matter how high the general level of child-family disruption is in the country.

In Table 4, we did not pay any attention to the marital status of a child's parents since the child itself perhaps not perceives this as a very important characteristic of its family. Nevertheless, the marital status of the parents has a strong effect on the probability that children will ever experience a family dissolution since consensual unions everywhere are much less stable than marriages are. In Table 5, we therefore give more detail to our presentation and report the fractions of children who ever experience a family disruption during childhood for children born in a consensual union and for those born in a marriage, separately. Our tabulation reveals that children born in a marriage typically have only half the probability of experiencing a family disruption during childhood as compared to children born in a consensual union. A similar excess instability is experienced by children born in consensual unions in practically every country in our study. If we again focus on differences between countries in family-disruption experiences of children, we find that the general patterns from Table 4 hold also when children born in the two types of family circumstances are presented separately. In both cases, we find that the USA is the country where children are most likely to experience a family disruption before they turn 15, closely followed by Latvia. In both cases, we also find Italy as the country where children have the lowest propensity for experiencing a family disruption. The patterns for Sweden turn out to be interesting. When children born in consensual unions and those born in marriage are treated separately, it no longer stands out as a country with particularly high levels of child-family disruptions. The relatively common experience of Swedish children of family dissolution, as indicated by Table 4, rather comes from the fact that so many children there are born to a cohabiting but not married couple. 
Table 6 summarizes the information gathered from Tables 2 and 4 in that it reports the cumulative percent of all children who ever have the experience of living outside a union of their two parents at the exact ages $0,1,3,9$, and 15. Children who are born to a lone mother here enter already at age 0 , i.e., at birth, while children who are born in a union and then at some point in time experience a union dissolution of their parents subsequently add to this initial fraction of children. The high fraction of births to lone mothers in the USA and the former GDR (Table 2) shows up in the first column of Table 6 . The last column of the same table shows that USA gets the highest fraction of children, as much as 50 percent, with any experience of living outside a two-parent family when they turn 15 . USA is closely followed by the GDR and Latvia, while in many Western and Eastern European countries it is more normal to find a fraction around a fourth or a third of all children with an experience of that kind at some time during childhood. A number of Catholic countries in various parts of Europe again stand out with lower levels than the average. Flanders, Spain, Slovenia, and Poland all have fractions below 20 percent and in Italy, only nine percent of all children ever have such an experience.

\section{3e. Children's experiences of family re-formation}

In Table 7, we demonstrate what happen to children who experience a union disruption of their parents in that we describe to what extent they again find themselves living in a union with their mother and a new partner of hers at a duration of exactly $1,3,6$, and 10 years after the family breakup ${ }^{3}$. High levels of entry into a stepfamily of children who have experienced a parental separation are found in the USA, the GDR, and the Czech Republic. In the two East European countries, around 30 percent of such children live in a new family already one year after the family breakup. Two thirds of such children in the three countries mentioned above have had the experience of living in a stepfamily at a duration of six years from the family

\footnotetext{
${ }^{3}$ In the calculation of this table, we censor an observation if a child moves away from the mother in order to live with the father, or on its own, since we then have no information on further changes in the living arrangements of that child.
} 
dissolution. In many cases, countries with a relatively high level of disruption rates of child families also exhibit higher levels of formation of new stepfamilies than other countries do. The lowest propensities of children to enter a new two-parent family are found in Italy and Poland. A calculation of mean values of the durations when children typically enter a stepfamily, calculated for the children who have had such an experience (not shown here), reveals that this event typically takes place around 3-4 years after a dissolution of the parental union.

\section{3f. A summary measure of children's experience of living in different types of families}

We conclude our presentation with a simple summary of the fractions of time that children in the different countries spend in various family types (Table 8). These percentages have simply been calculated from the family states that mothers reported for their children during the six-year period that came immediately before the interview date. We distinguish between time spent with a lone mother (with time spent after a family disruption and time spent immediately after childbirth given separately) and time that occurred after a child left its mother to live on its own or with someone else ${ }^{4}$. We also report the fractions of time that children typically spend with their original parents living in a consensual union and in a marriage, respectively. Finally, we report the fractions of time that children spend in a stepfamily. All summaries cover the time from birth to the $15^{\text {th }}$ birthday ${ }^{5}$.

As we might expect, we find the highest fraction of children living with a lone mother, or with no mother at all, for the USA. On average, children there spend as much as 22 percent of their childhood in a one-parent family (or in any family without

\footnotetext{
${ }^{4}$ The fractions of childhood spent in families where the mother is not present are generally very low and can actually be disregarded. They amount to a maximum of two percent in USA and Sweden and even less than that in the other countries considered. For Lithuania and Poland, we have no information on children's actual living arrangements so we here assume that they continue to live with their mother in the case of, for example, a family disruption. For Norway, we know if a child has left its mother but we have no information about the date of that event so we choose to exclude such children completely from our calculations. For France, we cannot distinguish if a child has died or moved away from its mother and here we censor our observation at the point when such an event occurs. In our Table 8, these four countries thus show up with 0 percent of children living away from their mother, a feature that they actually share with many countries where we indeed have the full information on the residential histories of children. ${ }^{5}$ Each age group of children have the same weight when we perform our summation so that our
summary measure not is affected by the current age distribution of respondents' children.
} 
their mother). Common averages for children in Europe rather stand at around 10 percent of childhood time in such families. Latvia is here found at the top with a figure of 15 percent while children in Flanders, Slovenia, Spain, and Italy only spend 3-6 percent of their entire childhood in a one-parent family. USA also stands out as the country where it is most common for children to live in a stepfamily; 10 percent of all childhood time is there accountable to that family type. In Europe, it is instead common to find that around 5 percent of childhood time belong to stepfamilies. The highest levels are recorded for children in the GDR, the Czech Republic, and Latvia (7-8 percent), while the lowest values are found for children in Italy, Spain, Slovenia, and Poland (0-2 percent).

A final conclusion from Table 8 is that children after all spend the vast majority of their childhood living with both their original parents. This figure is much lower for children in the USA than in any European country but even in the US we find that 67 percent of all childhood time refer to periods when children live with their two original parents. In Europe, this value ranges from a minimum of 79 percent in the former GDR and Latvia to a maximum of 97 percent for children in Italy. We can also see that practically all children who live with their original parents live in matrimony. Evidently, it is only in Sweden where it is very common for children to live with two cohabiting but not married parents: 17 percent of all childhood time is there spent in such families. It is interesting to note that USA and Sweden have exactly the same low fraction of childhood time accountable to periods when children live with their two original parents in marriage; the big difference is that in Sweden most of the remaining children live with their original parents in a consensual-union family while in USA they rather live with a lone mother or in a stepfamily.

\section{Conclusions}

Our presentation has revealed both striking differences and strong similarities between countries when it concerns patterns of family-demographic affairs of children. USA stands out as an extreme case with its very high fraction of children born to a lone mother, with a higher probability for children to experience a union disruption of their parents than anywhere else, and with many children having the experience of living in a stepfamily. Italy stands out at the other end of the scale. 
Practically all children are here born to a married mother and very few of them experience a dissolution of their parents' union before they turn 15 . The vast majority of children in Europe are born in a union and spend their entire childhood living with both of their original parents. The differences in family conditions between children in USA and children in Europe is impressive but important variation also exist between countries in Europe. Our study covers the family-demographic situation in a relatively large number of countries in Europe, from both sides of the former Iron Curtain. We do not find any systematic differences between countries in Eastern Europe and countries in Western Europe but rather a variation between countries within each sphere of the continent. Some European countries are characterised by particularly stable family patterns from the point of view of children. These countries are found in different areas of Europe but all have the trait in common of being strongly dominated by the Catholic confession. European countries with a higher degree of volatility in their family-demographic affairs are all characterised by a less influential role of religion in general and of Catholicism in particular. With the exception of Sweden, it is not really common for children to grow up in families with cohabiting but not married parents. Children born in cohabitation are exposed to higher disruption risks than children born in marriage so the general level of childfamily disruption is also related to the level of childbearing to cohabiting couples.

To conclude, we believe that our cross-country comparison has provided a lucid overview of the actual family-demographic situation of children in Europe and the US - and of existing differentials and similarities in patterns between countries. We found it particularly valuable to be able to get a number of East European countries into our picture so that we could compare the situation in these countries with the situation in Western Europe. Our study of Eastern Europe mainly covers the period around or just after the transition from the former situation of state socialism there. For the future, we recommend that descriptive measures of the kind we have presented here should be applied also to other demographic sources so that we can derive comparable information from yet further countries - and time periods. It would be interesting to get even more East European countries into our picture, in particular Russia and the various successor states of the former Soviet Union. In addition, it would be interesting to get Britain and further Anglo-Saxon countries into our crosscountry comparison. 


\section{Acknowledgments}

I am grateful to Dimiter Philipov for his cooperation in the production of the various life tables that have served as the basis for this paper. I am grateful to advice from Jan Hoem, Larry Bumpass, Ron Lesthaeghe, and Kathleen Kiernan in the setting up of our system of life tables (presented in Andersson and Philipov, 2001a,b). I thank the Advisory Group of the FFS programme of comparative research for its permission, granted under identification number 75 , to use the original FFS data on which this study is based. In addition, I am grateful to the Stockholm University Demography Unit for its permission to use the cleaned version of the Swedish FFS. Finally, I thank Friederike Seichter for practical assistance in putting all the tables together.

\section{References}

Alt, C., 2001. Kindheit in Ost und West: Wandel der Familialen Lebensformen aus Kindersicht. Leske+Budrich, Opladen, Germany.

Andersson, G., and Philipov, D., 2001a. Life-table representations of family dynamics in Sweden and Hungary: initiation of a project of descriptions of demographic behavior. MPIDR Working Paper, WP 2001-010. Max Planck Institute for Demographic Research, Rostock.

Andersson, G., and Philipov, D., 2001b. Life-table representations of family dynamics in 16 FFS countries. MPIDR Working Paper, WP 2001-024. Max Planck Institute for Demographic Research, Rostock.

Bumpass, L., and Hsien-Hen Lu, 2000. Trends in cohabitation and implications for children's family contexts in the United States. Population Studies 54: 29-41.

Bumpass, L., and Raley, K., 1995. Redefining single-parent families: Cohabitation and changing family reality. Demography 32: 97-109.

Dennis, M., 1999. The East German family: Change and continuity. In Flockton, I., et al. (eds), Recasting East Germany: Social Transformation after the GDR: 83101. Frank Cass, London.

Heuveline, P., and Timberlake, J., 2000. Towards a child-centered life course perspective on family structures: Multi-state early life tables using FFS data. Paper presented at the FFS Flagship Conference, Brussels, 29-31 May, 2000. 
Kiernan, K., 1999a. Cohabitation in Western Europe. Population Trends, No. 96, pp. 25-32.

Kiernan, K., 1999b. Childbearing outside marriage in Western Europe. Population Trends, No. 98, pp. 11-20.

Kiernan, K., 2000. The state of European unions: An analysis of FFS data on partnership formation and dissolution. Paper presented at the FFS Flagship Conference, Brussels, 29-31 May, 2000.

Klijzing, E., and Macura, M., 1997. Cohabitation and extra-marital childbearing: Early FFS evidence. International Population Conference, Beijing, 11-17 October 1997, Vol 2, pp. 885-901. IUSSP, Liège, Belgium.

Murphy, M., 2000. The evolution of cohabitation in Britain, 1960-95. Population Studies 54: 43-56.

Prinz, C., 1995. Cohabiting, Married or Single: Portraying, Analyzing and Modeling New Living Arrangements in the Changing Societies of Europe. Ashgate Publishing Co, Brookfield, Vermont.

Toulemon, L., 1997. Cohabitation is here to stay. Population: An English Selection 9: 11-56. 
Table 1: Number of female respondents, mothers, and children of respondents, by country

$\begin{array}{llrrr} & \text { country } & \text { women } & \text { mothers } & \text { children } \\ \text { "West" } & \text { Sweden } & 2986 & 2247 & 4638 \\ & \text { Norway } & 3969 & 2367 & 4523 \\ & \text { Finland } & 4040 & 2895 & 6043 \\ & \text { France } & 2930 & 2194 & 4527 \\ & \text { USA } & 10510 & 6609 & 14357 \\ & \text { Austria } & 4260 & 3217 & 6485 \\ & \text { W Germany } & 2743 & 1223 & 2113 \\ & \text { Flanders } & 3143 & 1911 & 3602 \\ & \text { Italy } & 4745 & 2858 & 5410 \\ & \text { Spain } & 3981 & 2450 & 4991 \\ \text { East" } & \text { E Germany } & 2810 & 2025 & 3437 \\ & \text { Hungary } & 3498 & 2622 & 4908 \\ \text { Czech Rep } & 1719 & 1222 & 2331 \\ \text { Slovenia } & 2761 & 2116 & 3953 \\ \text { Latvia } & 2622 & 2080 & 3787 \\ \text { Lithuania } & 2924 & 2113 & 3742 \\ \text { Poland } & 4165 & 3184 & 6752 \\ & & & \end{array}$


Table 2: Relative distribution of births (percent)

$\begin{array}{llll}\text { country period } & \begin{array}{l}\text { tolone } \\ \text { mother }\end{array} & \text { in consen- } \\ \text { marriage } & \text { sual union }\end{array}$

$\begin{array}{lcccc}\text { Sweden } & (1987-93) & 5 & 51 & 45 \\ \text { Norway } & (1983-89) & 7 & 71 & 22 \\ \text { Finland } & (1983-89) & 3 & 85 & 13 \\ \text { France } & (1988-94) & 10 & 68 & 23 \\ \text { USA } & (1989-95) & 17 & 72 & 11 \\ \text { Austria } & (1990-96) & 10 & 70 & 19 \\ \text { W Germany } & (1986-92) & 6 & 83 & 11 \\ \text { Flanders } & (1985-92) & 1 & 94 & 4 \\ \text { Italy } & (1990-95) & 2 & 94 & 4 \\ \text { Spain } & (1989-95) & 2 & 93 & 4 \\ \text { GDR } & (1984-89) & 18 & 67 & 15 \\ \text { Hungary } & (1988-93) & 3 & 90 & 6 \\ \text { Czech Rep } & (1992-97) & 4 & 89 & 7 \\ \text { Slovenia } & (1989-95) & 6 & 78 & 16 \\ \text { Latvia } & (1989-95) & 11 & 79 & 11 \\ \text { Lithuania } & (1989-95) & 5 & 93 & 2 \\ \text { Poland } & (1986-91) & 9 & 89 & 2\end{array}$


Table 3: Cumulative percent ever in union, by age of child, for children born to a lone mother

$\begin{array}{llccc}\text { country } & \text { period } & \underline{\text { age } 1} & \underline{\text { age 3 }} & \underline{\text { age } 9} \\ \text { Sweden } & (1987-93) & 19 & 29 & 52 \\ \text { Norway } & (1983-89) & 29 & 54 & -- \\ \text { Finland } & (1983-89) & 25 & 39 & 64 \\ \text { France } & (1988-94) & 8 & 13 & 38 \\ \text { USA } & (1989-95) & 18 & 37 & 65 \\ \text { Austria } & (1990-96) & 19 & 44 & 73 \\ \text { W Germany } & (1986-92) & 12 & 32 & -- \\ \text { Flanders } & (1985-92) & 5 & -- & -- \\ \text { Italy } & (1990-95) & 48 & -- & -- \\ \text { Spain } & (1989-95) & 46 & -- & -- \\ \text { GDR } & (1984-89) & 37 & 63 & 87 \\ \text { Hungary } & (1988-93) & 23 & 52 & -- \\ \text { Czech Rep } & (1992-97) & 17 & -- & -- \\ \text { Slovenia } & (1989-95) & 42 & 66 & 85 \\ \text { Latvia } & (1989-95) & 25 & 52 & 69 \\ \text { Lithuania } & (1989-95) & 21 & 32 & -- \\ \text { Poland } & (1986-91) & 17 & 25 & 32\end{array}$


Table 4: Cumulative percent ever out of union, by age of child, for children born in a union

$\begin{array}{llcccc}\text { country } & \text { period } & \text { age 1 } & \text { age 3 } & \text { age 9 } & \text { age 15 } \\ \text { Sweden } & (1987-93) & 2 & 9 & 21 & 30 \\ \text { Norway } & (1983-89) & 2 & 6 & 15 & 21 \\ \text { Finland } & (1983-89) & 1 & 6 & 14 & 20 \\ \text { France } & (1988-94) & 2 & 6 & 16 & 23 \\ \text { USA } & (1989-95) & 5 & 14 & 29 & 40 \\ \text { Austria } & (1990-96) & 2 & 6 & 18 & 26 \\ \text { W Germany } & (1986-92) & 2 & 6 & 16 & 29 \\ \text { Flanders } & (1985-92) & 1 & 3 & 10 & 15 \\ \text { Italy } & (1990-95) & 0 & 1 & 4 & 7 \\ \text { Spain } & (1989-95) & 1 & 3 & 7 & 10 \\ \text { GDR } & (1984-89) & 2 & 8 & 24 & 34 \\ \text { Hungary } & (1988-93) & 1 & 4 & 14 & 22 \\ \text { Czech Rep } & (1992-97) & 2 & 7 & 17 & 25 \\ \text { Slovenia } & (1989-95) & 1 & 2 & 6 & 10 \\ \text { Latvia } & (1989-95) & 5 & 13 & 28 & 38 \\ \text { Lithuania } & (1989-95) & 2 & 5 & 16 & 25 \\ \text { Poland } & (1986-91) & 1 & 2 & 6 & 10\end{array}$



Table 5: Cumulative percent ever out of union, by age of child, for children born in a:

\begin{tabular}{llcccc|cccc} 
& \multicolumn{7}{c}{ consensual union } & \multicolumn{5}{c}{ marriage } \\
country & period & age 1 & age 3 & age 9 & age 15 & age 1 & age 3 & age 9 & age 15 \\
Sweden & $(1987-93)$ & 4 & 13 & 27 & 38 & 1 & 5 & 15 & 24 \\
Norway & $(1983-89)$ & 8 & 18 & 30 & 36 & 1 & 4 & 12 & 18 \\
Finland & $(1983-89)$ & 4 & 19 & 35 & 39 & 1 & 4 & 11 & 17 \\
France & $(1988-94)$ & 5 & 16 & 35 & 58 & 1 & 3 & 11 & 17 \\
USA & $(1989-95)$ & 18 & 39 & 64 & 78 & 3 & 10 & 24 & 35 \\
Austria & $(1990-96)$ & 6 & 13 & 31 & 43 & 1 & 4 & 15 & 23 \\
W Germany & $(1986-92)$ & 4 & 16 & 37 & -- & 1 & 5 & 13 & 26 \\
Flanders & $(1985-92)$ & 4 & 15 & 34 & -- & 1 & 2 & 9 & 14 \\
Italy & $(1990-95)$ & 0 & 2 & 7 & -- & 0 & 1 & 4 & 7 \\
Spain & $(1989-95)$ & 9 & 24 & -- & -- & 1 & 2 & 6 & 9 \\
GDR & $(1984-89)$ & 6 & 19 & 38 & -- & 1 & 6 & 21 & 31 \\
Hungary & $(1988-93)$ & 7 & 17 & 48 & 58 & 1 & 4 & 12 & 20 \\
Czech Rep & $(1992-97)$ & 9 & 27 & -- & -- & 1 & 5 & 15 & 24 \\
Slovenia & $(1989-95)$ & 3 & 8 & 14 & 19 & 0 & 1 & 5 & 8 \\
Latvia & $(1989-95)$ & 16 & 36 & 58 & 69 & 3 & 10 & 24 & 34 \\
Lithuania & $(1989-95)$ & 15 & -- & -- & -- & 1 & 5 & 15 & 24 \\
Poland & $(1986-91)$ & 0 & 12 & 26 & -- & 1 & 2 & 5 & 10
\end{tabular}


Table 6: Cumulative percent ever out of union, by age of child

$\begin{array}{llccccc}\text { country } & \text { period } & \text { at birth } & \text { age 1 } & \text { age 3 } & \text { age 9 } & \text { age 15 } \\ \text { Sweden } & (1987-93) & 5 & 7 & 13 & 24 & 34 \\ \text { Norway } & (1983-89) & 7 & 9 & 13 & 21 & 26 \\ \text { Finland } & (1983-89) & 3 & 4 & 8 & 16 & 22 \\ \text { France } & (1988-94) & 10 & 12 & 15 & 24 & 31 \\ \text { USA } & (1989-95) & 17 & 21 & 28 & 41 & 50 \\ \text { Austria } & (1990-96) & 10 & 12 & 15 & 26 & 34 \\ \text { W Germany } & (1986-92) & 6 & 8 & 12 & 21 & 34 \\ \text { Flanders } & (1985-92) & 1 & 2 & 4 & 11 & 17 \\ \text { Italy } & (1990-95) & 2 & 2 & 3 & 6 & 9 \\ \text { Spain } & (1989-95) & 2 & 3 & 5 & 9 & 13 \\ \text { GDR } & (1984-89) & 18 & 19 & 25 & 37 & 46 \\ \text { Hungary } & (1988-93) & 3 & 5 & 8 & 17 & 24 \\ \text { Czech Rep } & (1992-97) & 4 & 6 & 11 & 20 & 29 \\ \text { Slovenia } & (1989-95) & 6 & 7 & 8 & 12 & 15 \\ \text { Latvia } & (1989-95) & 11 & 15 & 22 & 35 & 44 \\ \text { Lithuania } & (1989-95) & 5 & 7 & 10 & 20 & 29 \\ \text { Poland } & (1986-91) & 9 & 10 & 11 & 14 & 18\end{array}$


Table 7: Cumulative percent ever again in a union, by time since union disruption, for children experiencing parental separation

\begin{tabular}{|c|c|c|c|c|c|}
\hline & & & duration & & \\
\hline country & period & 1 year & $\underline{3 \text { years }}$ & 6 years & 10 years \\
\hline Sweden & $(1987-93)$ & 11 & 32 & 51 & 62 \\
\hline Norway & $(1983-89)$ & 17 & 41 & 57 & -- \\
\hline Finland & $(1983-89)$ & 15 & 31 & 45 & 64 \\
\hline France & (1988-94) & 10 & 23 & 35 & 47 \\
\hline USA & $(1989-95)$ & 21 & 47 & 67 & 78 \\
\hline Austria & $(1990-96)$ & 18 & 30 & 47 & 54 \\
\hline W Germany & $(1986-92)$ & 8 & 29 & 50 & -- \\
\hline Flanders & $(1985-92)$ & 21 & 37 & 54 & -- \\
\hline Italy & $(1990-95)$ & 2 & 8 & 28 & -- \\
\hline Spain & $(1989-95)$ & 5 & 25 & 37 & 47 \\
\hline GDR & (1984-89) & 28 & 55 & 65 & -- \\
\hline Hungary & $(1988-93)$ & 15 & 39 & 57 & 68 \\
\hline Czech Rep & (1992-97) & 32 & 61 & 71 & 77 \\
\hline Slovenia & $(1989-95)$ & 14 & 36 & 62 & 71 \\
\hline Latvia & $(1989-95)$ & 16 & 32 & 43 & 60 \\
\hline Lithuania & $(1989-95)$ & 9 & 25 & 43 & 57 \\
\hline Poland & (1986-91) & 7 & 19 & 25 & 38 \\
\hline
\end{tabular}


Table 8: Percent of time spent in different family types at ages 0-14 years

\begin{tabular}{|c|c|c|c|c|c|c|c|c|c|}
\hline \multirow[b]{2}{*}{ country } & \multirow[b]{2}{*}{ period } & \multicolumn{4}{|c|}{ time with lone mother: } & \multicolumn{3}{|c|}{ time with both parents: } & \multirow{2}{*}{$\begin{array}{l}\text { time in step } \\
\text { family: } \\
\text { (with mother }\end{array}$} \\
\hline & & - from birth & $\begin{array}{l}\text { - after } \\
\text { disruption }\end{array}$ & $\begin{array}{l}\text { with no } \\
\text { mother }\end{array}$ & $\begin{array}{l}=>\text { total } \\
\text { lone/no } \mathrm{m} \text {. }\end{array}$ & cohabitation & marriage & $\begin{array}{l}==>\text { total } \\
\text { both parents }\end{array}$ & \\
\hline Sweden & $(1987-93)$ & 2 & 9 & 2 & 12 & 17 & 64 & 81 & 6 \\
\hline Norway & $(1983-89)$ & 2 & 5 & 0 & 7 & 5 & 84 & 89 & 4 \\
\hline Finland & $(1983-89)$ & 1 & 6 & 1 & 8 & 4 & 84 & 88 & 4 \\
\hline France & $(1988-94)$ & 4 & 7 & 0 & 11 & 8 & 78 & 86 & 3 \\
\hline USA & (1989-95) & 7 & 13 & 2 & 22 & 4 & 64 & 67 & 10 \\
\hline Austria & $(1990-96)$ & 4 & 8 & 1 & 12 & 6 & 79 & 84 & 4 \\
\hline W Germany & $(1986-92)$ & 2 & 8 & 1 & 12 & 5 & 78 & 83 & 5 \\
\hline Flanders & $(1985-92)$ & 0 & 4 & 0 & 5 & 1 & 91 & 92 & 3 \\
\hline Italy & $(1990-95)$ & 0 & 2 & 0 & 3 & 1 & 95 & 97 & 0 \\
\hline Spain & $(1989-95)$ & 1 & 3 & 0 & 4 & 1 & 93 & 94 & 1 \\
\hline GDR & (1984-89) & 5 & 8 & 1 & 13 & 6 & 73 & 79 & 8 \\
\hline Hungary & $(1988-93)$ & 1 & 6 & 0 & 8 & 2 & 86 & 87 & 5 \\
\hline Czech Rep & (1992-97) & 1 & 6 & 0 & 8 & 2 & 84 & 85 & 7 \\
\hline Slovenia & $(1989-95)$ & 2 & 3 & 1 & 6 & 6 & 86 & 92 & 2 \\
\hline Latvia & (1989-95) & 3 & 11 & 0 & 15 & 3 & 75 & 79 & 7 \\
\hline Lithuania & $(1989-95)$ & 2 & 8 & 0 & 10 & 1 & 85 & 86 & 3 \\
\hline Poland & (1986-91) & 5 & 3 & 0 & 9 & 1 & 90 & 90 & 1 \\
\hline
\end{tabular}

